\section{Cientific Paper}

\section{Abstract}

The objective of the study was to evaluate the effect of different periods of the interference of species of weeds on the lettuce in greenhouses. It was used a randomized experimental design in blocks with four replications, evaluating four period prior to interference - PPI, which were: $0,10,15,20,25$ days after the transplantation. It was determined the number by species $\left(\mathrm{m}^{-2}\right)$ and fresh and dry mass of weeds $\left(\mathrm{g} \mathrm{m}^{-2}\right)$, the head diameter $(\mathrm{cm})$, number of

\title{
Effects of the different periods of weed interference on lettuce in protected cultivation
}

ldon Rodrigues Nascimento ${ }^{1}$ Horllys Gomes Barreto ${ }^{2}$ Prínscilla Pâmela Nunes Chaves ${ }^{3}$ Eduardo Andrea Lemus Erasmo ${ }^{1}$ Valéria Gomes Momenté ${ }^{1}$ leaves and fresh and dry mass of shoots $\left(\mathrm{g} \mathrm{m}^{-2}\right)$ of the lettuce. The accumulated dry mass of the weeds correlated inversely proportional to the assessed characteristics in the lettuce crop. The most affected characteristic by the competition with weed plants was the stem diameter and number of leaves. The weed control in lettuce crop should start soon after transplanting of the seedlings.

Keywords: Lactuca sativa L.; competition; weed.

\section{Efeitos de diferentes períodos de interferências de plantas daninhas em alface sobre cultivo protegido}

\section{Resumo}

O objetivo do trabalho foi avaliar o efeito de diferentes períodos de interferência de espécies de daninhas sobre a alface em cultivo protegido. Utilizou-se o delineamento experimental em blocos casualizados, com quatro repetições, avaliando-se quatro períodos anteriores de interferência - PAI, que foram: 0; 10; 15; 20; 25 dias após o transplante. Foi determinado o número por espécie $\left(\mathrm{m}^{-2}\right)$ e massa fresca e seca das plantas daninhas $\left(\mathrm{g} \mathrm{m}^{-2}\right)$, o diâmetro da cabeça $(\mathrm{cm})$, o número de folhas e a massa fresca e seca da parte aérea $\left(\mathrm{g} \mathrm{m}^{-2}\right)$ da alface. A massa seca acumulada das plantas daninhas apresentou correlação inversamente proporcional às características avaliadas na cultura da alface. A característica mais afetada pela competição com plantas daninha foi o diâmetro do caule e no número de folhas. O controle das plantas daninhas na cultura da alface deve iniciar logo após o transplante das mudas.

Palavras-chave: Lactuca sativa L.; competição; planta daninha.

\section{Efectos de diferentes períodos de interferencia de malas hierbas en lechuga en cultivos protegidos}

\section{Resumen}

El objetivo de este estudio fue evaluar el efecto de diferentes períodos de interferencia de especies de malas hierbas sobre la lechuga en cultivo protegido. Se utilizó un diseño de bloques completos al azar con cuatro repeticiones, evaluando cuatro períodos anteriores de interferencia - PAI , que fueron: 0, 10, 15, 20 y 25 días después del trasplante. Se determinó el número por especie $\left(\mathrm{m}^{-2}\right)$ y el peso fresco y peso seco de las malas hierbas $\left(\mathrm{g} \mathrm{m}^{-2}\right)$, el diámetro de la cabeza $(\mathrm{cm})$, número de hojas y peso fresco y seco de la parte aérea de la planta $\left(\mathrm{g} \mathrm{m}^{-2}\right)$ de la lechuga. La acumulación de materia seca de las malas hierbas se mostró inversamente proporcional a las características evaluadas en la lechuga. Las características más afectadas por la competencia con malas hierbas fueran el diámetro del tallo y número de hojas. El control de las malas hierbas en plantas de lechuga debe comenzar poco después del trasplante.

Palabras clave: Lactuca sativa L.; competencia; hierbas invasoras.

Received at: 06/12/2012 Accepted for publication: 28/07/2013
1 Agronomist Engineer-DR., Professor Universidade Federal do Tocantins/UFT. Caixa Postal 66, 77410-000, Gurupi, TO. E-mail: ildon@
uft.edu.br
2 Post Graduate Student - Biotecnologia Vegetal - Universidade Federal de Lavras/UFLA. E-mail: horllys@hotmail.com
3 Agronomist Engineer-DR. Professor Universidade Federal do Tocantins/UFT. E-mail: prinscilla_@hotmail.com

Applied Research \& Agrotecnology v6 n2 may/aug. (2013)

Print-ISSN 1983-6325 (On line) e-ISSN 1984-7548 


\section{Introduction}

In the cultivation of vegetables, the control of weeds is different of the normally implemented on larger crops. Cultural practices as the high mobilization of the soil, frequent and abundant irrigations and the intensive use of plants at the same area during the whole year, favor the development of the plants (HORTA et al., 2004).

The lettuce (Lactuca sativa L.) is an annual dicotyledonous vegetable of the Asteraceae family. It is the most consumed and popular leafy vegetable (ZARÂTE et al., 2010), and can be cultivated either in open field or in greenhouses. In the Tocantins State, the lettuce is cultivated in all regions, with predominance of the cultivations in greenhouses, condition which favors the yield and economical potential of the crop and also the development of the weed, especially at the summer.

In the lettuce production, the use of seedlings produced in trays provides quick post transplantation growth, as well as a stand virtually without failures (SILVA et al., 1999). However, even in these conditions, the weed plants are competitive and reduce significantly the lettuce yield. According to SANTOS et al. (2004), the increase of the competitive ability of the lettuce, in relation to the weeds, can be achieved with the distribution and incorporation of fertilizers close to the lettuce root system.

It can be determined the period in which the presence of weed plants interferes in the yield of the cultivated crop, seeking to determine the periods or seasons which are critical in the interaction between these crops and the infesting plants. Such periods are defined as Period Prior to Interference - PPI, Total Period of Interference Prevention TPIP and Critical Period of Interference CPI (PITELLI and DURIGAN, 1984). The knowledge of such periods is of extreme importance for the development of management strategies for weed plants, indicating the time interval when the chemical or non chemical control is going to be more effective in the prevention of damages to the cultivated plants (SWANTON and WEISE, 1991).

The Period Prior to Interference - PPI, is the period in which, from the emergence or sowing of the crop, this can live together with the species of weeds before its yield or other characteristics are negatively affected (SALVADOR, 2006). For this characteristic, the estimative of the PPI becomes important for the management of weeds in the vegetables.

SHREFLER et al. (1994) verified that after seven weeks of interference of the A. spinosus in the lettuce crops, the biomass of the lettuce aerial par reduced around $20 \%$ in relation to the control treatment (free of weeds). In another study, it was not observed yield losses in the lettuce crop maintained free of weeds for three weeks (ROBERT et al., 1977).

Conditions of soil and weather can drastically modify the relations between weeds and the other crops (MESCHEDE et al., 2002). This behavior contributes in such way that experimental results completely different can be obtained in distinct places.

Thus, to obtain reliable data on the interference effects, there is the necessity of making studies in the most varied conditions.

Facing these aspects, the objective of the study was to assess the effect of the Period Prior to Interference (PPI) of the weeds on components of lettuce crop cultivations in greenhouse.

\section{Material and Methods}

The experiment was carried out in a greenhouse at the Sector of Vegetable Crops of the Universidade Federal de Tocantins, Campus Gurupi, situated at $11^{\circ} 43^{\prime} 45^{\prime \prime} \mathrm{S}, 49^{\circ} 04^{\prime} 07^{\prime \prime} \mathrm{W}$ and average altitude of $280 \mathrm{~m}$. It was used a cultivar of crisp lettuce "Elba", for being one of the most used by the producers of the region.

The seedlings were obtained in trays of expanded polystyrene of 128 cells, containing commercial substrate. After the germination, was done the thinning at the 10 days after the sowing, leaving a plant per cell. With 20 days after the sowing was done the transplantation of seedlings to seedbeds of $1.20 \mathrm{~m}$ wide.

The experiment was installed in a greenhouse with plastic cover. The experimental design use was randomized blocks with four repetitions and 50 plants per experimental unit, with spacing of $25 \times 25 \mathrm{~cm}$ between plants. The useful area for the evaluations comprehended the three central rows of plants, not considering the rows of the edges in the longitudinal and transverse directions to the seedbed, totalizing 24 sampled plants per experimental unit. The irrigation was made by dripping and the fertilizations were done according with the analysis of the soil as the recommendation for the crop.

The experimental treatments were established with base in the Period Prior to Interference - PPI, in which the crop remained in the presence of 
Effects of the different periods of weed... Efeitos de diferentes períodos de interferências... Efectos de diferentes períodos de interferencia... weeds since its emergence $(0,15,20$ and 25 after the transplanting). After these periods, according with the treatment, through manual weeding, the crop remained free of weeds until the harvest.

The weeds were sampled with the auxiliary of a cast iron frame with dimensions of $50 \mathrm{~cm} \mathrm{x}$ $50 \mathrm{~cm}$. The weeds present in each frame within each experimental unit were cut close to the soil, determining the species, the number of weeds NUMWE (in $\mathrm{m}^{-2}$ ) and the dry mass of the weeds DMW (in $\mathrm{g} \mathrm{m}^{-2}$ ), which was obtained in a greenhouse with ventilation at $65^{\circ} \mathrm{C}$ up to the constant weight. At the 45 days after the transplantations was done the harvest of the lettuce in the different treatments, assessing the following characteristics: head diameter (HD in $\mathrm{cm}$ ); number of leaves (NL); fresh (FM) and dry mass (DM) of the aerial part $\left(\mathrm{g} \mathrm{m}^{-2}\right)$.

The statistical analyses were done by the program Genes (CRUZ, 2006). With the average of each repetition, the coefficients of correlations of Pearson $(p=0.05)$ were estimated between the assessed characteristics. In function of the initial periods of interference, the analyses of variances were done and equations of regression were adjusted, in such that explained the behavior of each variable.

\section{Results and Discussion}

From the weed plants present in the experimental area stood out in quantity the Digitaria horizontalis L. Wild, Spermacoce latifolia Aubl, Cyperus rotundus and the Euphorbia heterophyla L. These species constituted $83.8 \%$ of the spontaneous weed plants (Table 1), being found regularly in the vegetables cultivations (PEREIRA, 1987; PAULO et al., 1990; PEREIRA, 2000; HORTA et al., 2004).

The development of the weeds depends of their capacity in using the resources of the environment. In the cultivations, these resources generally are not limited, making some species to have a favored growth (NASCENTE et al., 2004). Species such as the Digitaria horizontalis L. Wild, Spermacoce latifolia Aubl and the Cyperus rotundus, which presented high capacity of initial development, were in the greenhouse environment, those that apparently presented the greatest capacity of competition with the lettuce crop, which after the transplantation has a slow initial growth.

The accumulated dry mass and the number of weeds presented a significant correlation and inversely proportional to the characteristics assessed in the lettuce crop (Table 2), showing that these two

Table 1. Numbers per species of weed plants (converted in $\mathrm{m}^{2}$ ) in different prior periods of interference in the lettuce crop (curly cv. Elba).

\begin{tabular}{cccccccc}
\hline \multirow{2}{*}{ PPI } & \multicolumn{7}{c}{ Number of weed plants $\left(\mathrm{m}^{-2}\right)$} \\
\cline { 2 - 7 } & 1 & 2 & 3 & 4 & 5 & 6 & Total \\
\hline $0-0$ & 0.00 & 0.00 & 0.00 & 0.00 & 0.00 & 0.00 & 0.00 \\
$0-15$ & 28.00 & 11.00 & 8.00 & 3.00 & 32.00 & 14.00 & 96.00 \\
$0-20$ & 10.00 & 74.00 & 30.00 & 1.00 & 46.00 & 15.00 & 176.00 \\
$0-25$ & 7.00 & 36.00 & 2.00 & 12.00 & 15.00 & 13.00 & 85.00 \\
Total & 45.00 & 121.00 & 40.00 & 16.00 & 93.00 & 42.00 & 357.00 \\
\hline
\end{tabular}

*Where: 1 - Cyperus rotundus L.; 2 - Digitaria horizontalis L. Wild; 3 - Euphorbia heterophylla L.; 4 -Eleusine coracana (L.) Gaertn; 5 - Spermacoce latifólia Aubl; and 6 others.

Table 2. Estimative of the correlation coefficient between variables related to weed plants and the lettuce crop, under the effect of different prior periods of interference.

\begin{tabular}{cccccc}
\hline Variáveis & MSDAN & DC & NF & MFPA & MSPA \\
\hline NUMDAN & $0.28^{\text {ns }}$ & $-0.52^{*}$ & $-0.56^{*}$ & $-0.59^{*}$ & $-0.56^{*}$ \\
MSDAN & & $-0.70^{* *}$ & $-0.73^{* *}$ & $-0.72^{* *}$ & $0.79^{* *}$ \\
DC & & $0.76^{* *}$ & $0.84^{* *}$ & $0.95^{* *}$ & $0.96^{* *}$ \\
NF & & & $0.97^{* *}$ \\
MFPA & & & & \\
\hline
\end{tabular}

NUMWE: Number of weeds $\left(\mathrm{m}^{-2}\right)$; DMW: Dry mass of the weeds $\left(\mathrm{g} \mathrm{m}^{-2}\right)$; HD: Head diameter $(\mathrm{cm})$; NL: Number of leaves; FMAP: Fresh mass of the aerial part $\left(\mathrm{g} \mathrm{m}^{-2}\right)$; DMAP: Dry mass of the aerial part $\left(\mathrm{g} \mathrm{m}^{-2}\right)$ of the lettuce plants.

****: Meaningful at 5 and $1 \%$ of probability, respectively by the " $T$ " test 
variables are important in the assessment of the effect of the coexistence period of weeds for this crop.

By the values of estimates of the correlation coefficients (greater absolute values) of fresh mass of the weeds, it can be observed that this variable is a more efficient indicator than the number of weed plants, in what refers to the degree of interference imposed by the weeds. These results are similar to the observed in the literature (FREITAS et al., 2004; SOARES et al., 2003; MESCHEDE et al., 2004).

As it was increased the initial period of coexistence of the weed plants with the lettuce crop (Figure 1), there was also an increase in the dry mass and in the number of weed plants present.

The dry mass accumulation of the weeds continues to growth even after the reduction of density, being explained by the fact that the even occurring a restriction in the number of plants after certain period, by the inhibition of germination of the seeds of these weeds, the plants which had already established presented a vigorous growth, compensating in this way the reduction in the germination and the consequent increase of the dry matter. Similar results were obtained by QASEM (1992); KUVA et al. (2003) and NASCENTE et al. (2004) who related this behavior for these two characteristics.

The reduction of the number of weeds in function of the prior period of interference is due to the closing between the lines of transplantation by the crop, preventing the growth of new plants. However, plants which had already established after this period, are still capable of promoting a significant reduction in the crop yield, which normally do not occurs in crops that are higher sized, such as the sunflower (BRIGHENTI et al., 2004), soybean (MESCHEDE et al., 2004) and sorghum (ANDRES et al., 2009).

It was observed reduction in the head diameter and number of leaves. The equations which describe these characteristics in functions of the periods of interference are presented in Figure 2.

The minor development of a crop, especially as for the leaf area, instead of the development of the stalk is a dispositive from the crop to minimize the effect of the weeds, thus compromising its growth and progress. MELHORANÇA FILHO et al. (2008) related that the competition in the early stages of development of the crop do not necessarily entails in future losses. However, GARCIA et al. (1982) stated that the slowness of growth, especially of the aerial part of the lettuce crop in the early stages of development, would be the factor of greater sensitivity to the competition.

Comparing the treatment with control of weeds and the treatment submitted to periods of increasing interference, it is observed that there was a reduction of around $38 \%$ and $52 \%$, respectively, of the yield of dry and fresh mass of the lettuce plants, when submitted to 25 days of interference (Figure 3).

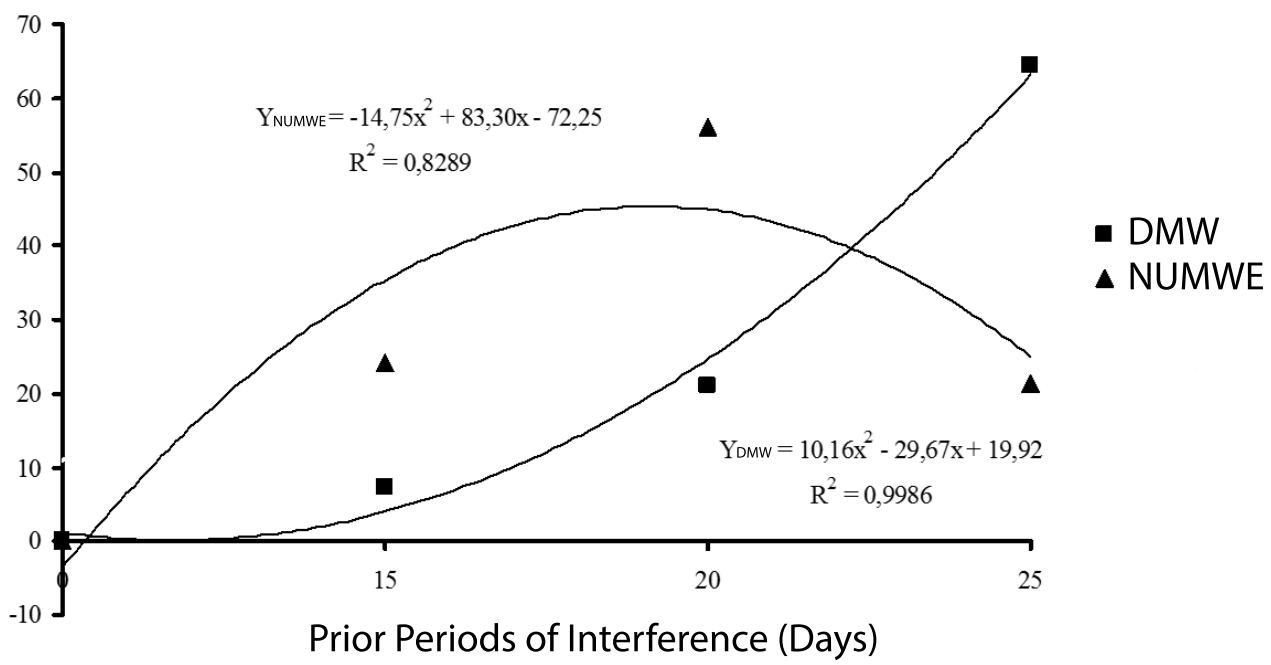

Figure 1. DMW - Dry mass of the weeds $\left(\mathrm{g} \mathrm{m}^{-2}\right)$ e NUMWE - Number of weeds $\left(\mathrm{m}^{-2}\right)$ in function of different prior periods of inference in the lettuce crop (curly cv. Elba). 
Effects of the different periods of weed...

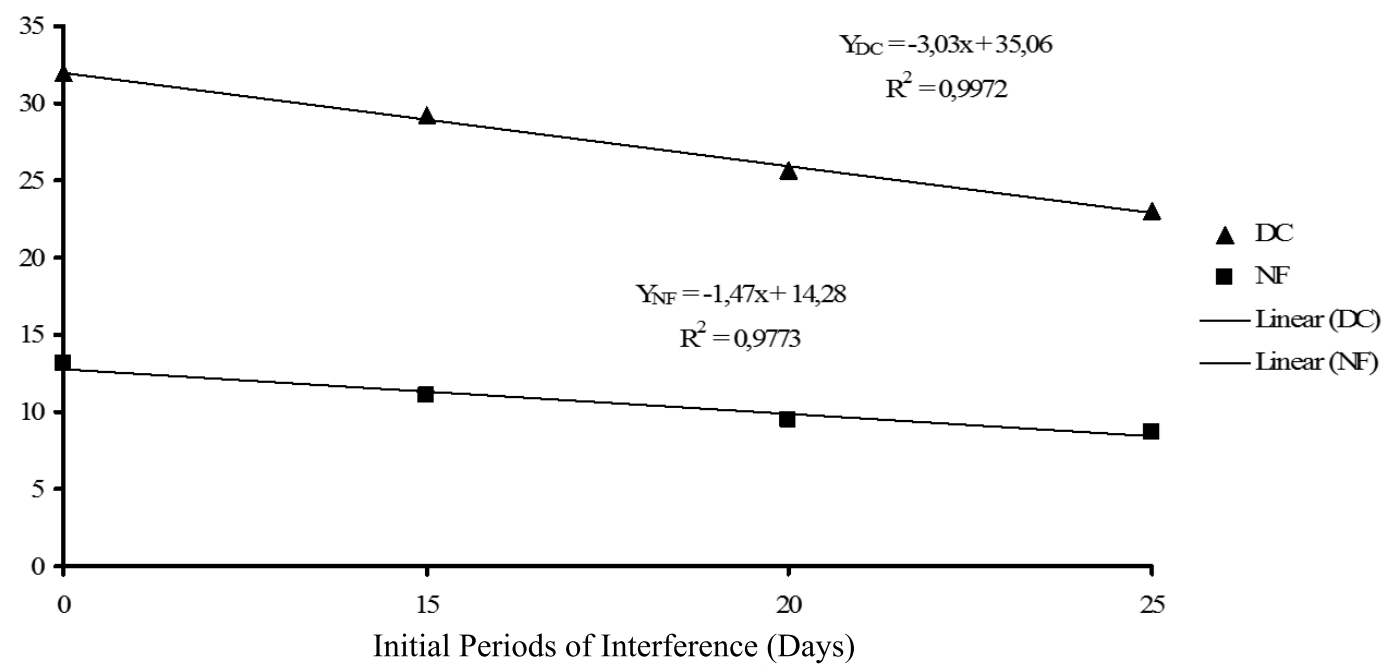

Figure 2. HD - Head Diameter (cm) and NL - Number of leaves in the lettuce (curly cv. Elba) in function of the different initial periods of interference with weeds.

In this period, each day of coexistence of the weeds with the lettuce crop, generated a loss estimated around 20.01 and 0.78 grammas per square meter of fresh mass, respectively. This fact indicated a relative sensibility of the lettuce to initial competition with the weeds, even when it is used the installation of the crop with transplantation of seedlings. MELHORANÇA FILHO et al. (2008) showed that the interference of weeds in the lettuce crop is greater between 20 to $30 \mathrm{DAT}$, causing a reduction of around $25 \%$ of fresh mass of the plants aerial part. SANCHEZ (1999) and GARCIA et al. (1982) affirm that the slowness of dry and fresh mass accumulation in the early cycle constitutes the main factor of sensibility to competition, especially since in this period the transplanted crop is still establishing. Under normal conditions of used spacing, the studies showed that the prior periods of interference are situated between the 20 and 25 DAT (APPEZZATO et al., 1983; PAULO et al., 1990; SANCHEZ, 1999; MELHORANÇA FILHO et al., 2008), agreeing with the results obtained in this study.

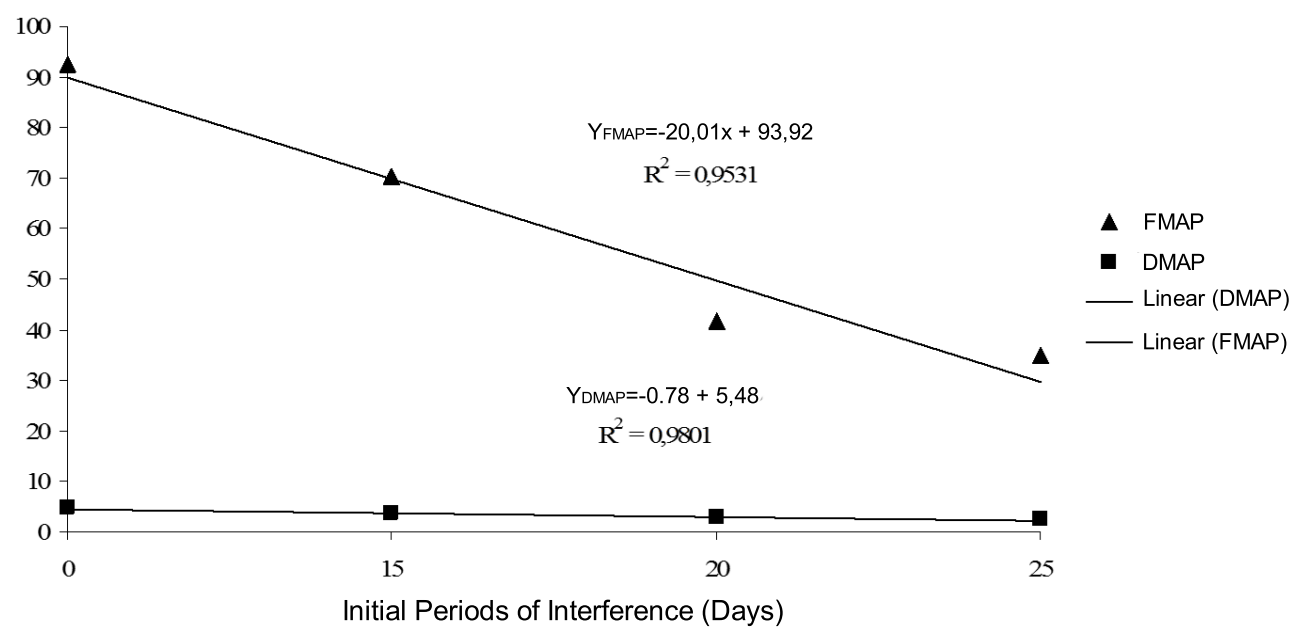

Figure 3. Fresh (FMAP) and dry mass (DMAP) of the aerial part $\left(\mathrm{g} \mathrm{m}^{-2}\right)$ in the lettuce (curly cv. Elba), in function of the different initial periods of interference with weeds. 


\section{Conclusions}

The accumulated dry mass of the weeds presented inversely proportional correlation to the assessed characteristics in the lettuce crop.

The most affected characteristic by the competitions with weeds was the stalk diameter and the number of leaves.

The control of the weeds in the lettuce crop must be initialized soon after the transplantation of seedlings.

\section{Acknowledgements}

To the CNPq, by the concession of a scholarship to the first author and to the Universidade Federal de Tocantins, Campus Gurupi, by financial aid to the research.

\section{References}

ANDRES, A.; CONCENÇO, G.; SCHWANKE, A.M.L.; THEISEN, G.; MELO, P.T.B.S. Períodos de interferência de plantas daninhas na cultura do sorgo forrageiro em terras baixas. Planta Daninha, v.27, n.2, p.229-234, 2009.

APPEZZATO, B.; TERAO, D.; CHRISTOFOLETI, P.J.; PIEDADE, S.M. de S.; VICTORIA FILHO, R. Competição de plantas daninhas com a cultura da alface (Lactuca sativa cv. Babá). Revista o Solo, v.75, n.2, p. 5-10, 1983.

BRIGHENTI, A.M.; CASTRO, C.; OLIVEIRA JUNIOR, R.S.; SCAPIM, C.A.; VOLL, E.; GAZZIERO, D. L. P. Períodos de interferência de plantas daninhas na cultura do girassol. Planta Daninha, v.22, n.2, p. 251-257, 2004.

CRUZ, C. D.2006. Programa Genes: Análise Multivariada e Simulação.Viçosa, UFV, 175p.

FREITAS, R.S.; SEDIYAMA, M.A.N.; PEREIRA, P.C.; FERREIRA, F.A.; CECON, P.R.; SEDITAMA, T. Períodos de interferência de plantas daninhas na cultura da mandioquinha-salsa. Planta Daninha, v.22, n.4, p. 449506. 2004.

GARCIA, L.L.C.; HAAG H.P.; NETO, V.D. Nutrição mineral de hortaliças. Deficiência de macronutrientes em alface (Lactuca sativa L.) cv. Brasil 48 e Clause's Aurélia. In: Anais da Escola Superior de Agricultura Luiz de Queiroz, Piracicaba, v.39, n.1, 1982. p.349-362.

HORTA, A.C.S.;SANTOS, H.S.; CONSTANIN, J.;SCAPIM, C.A. Interferência de plantas daninhas na beterraba transplantada e semeada diretamente. Acta Scientiarum. Agronomy, v.26, n.1, p. 47-53, 2004.

KUVA, M.A.; GRAVENA, R.; PITELLI, R.A.; CHRISTOFFOLETI, P.J.; ALVES, P.L.C.A. Períodos de interferência das plantas daninhas n cultura da cana-de-açúcar. III - capim-braquiária (brachiaria decumbens) e capim-colonião (panicum maximum) Planta Daninha, v.21, n.1, p.37- 44, 2003.

MELHORANÇA FILHO, A.L.; PEREIRA, M.R.; MARTINS, D.; CASTRO, R.M.; NASCIMENTO, M.S. Produtividade de alface cv. Lucy Brown influenciada por períodos de convivência com plantas infestantes e potencial alelopático da tiririca. Bioscience Journal, v.24, n.3, p.19-23, 2008.

MESCHEDE, D.K. Período crítico de interferência de Euphorbia heterophylla na cultura da soja sob baixa densidade de semeadura. Planta Daninha, v.20, n.3, p.381-387, 2002.

MESCHEDE, D.K.; OLIVEIRA JÚNIOR, R.S.; CONSTANTIN, J.; SCAPIM, C.A. Período anterior a interferência de plantas daninhas em soja: Estudo de caso com baixo estande e testemunhas duplas. Planta daninha, v.22, n.2, p.239-246, 2004.

NASCENTE, A.S.; PEREIRA, W.; MEDEIROS, M.A. Interferência das plantas daninhas na cultura do tomate para processamento. Horticultura Brasileira, v.22, n.3, p.602-606, 2004.

PAULO, E.M.; FUJWARA, M.; NISHIDA, T. Controle das plantas daninhas na cultura de alface transplantada com o herbicida oxadiazom. Bragantia, v.49, p.403-411, 1990. 
Effects of the different periods of weed...

Efeitos de diferentes períodos de interferências...

Efectos de diferentes períodos de interferencia...

PEREIRA, W. Manejo de plantas daninhas em hortaliças. Brasília: Embrapa- CNPH, 1987. 18p. (Boletim Técnico, 4).

PEREIRA, W. Manejo de plantas daninhas. In: SILVA, J.B.C.; GOORDANO, L.B. Tomate para processamento industrial. Brasília: Embrapa Comunicação para Transferência de Tecnologia/Embrapa Hortaliças, 2000. p. 72-87.

PITELLI, R.A.; DURIGAN, J.C. Terminologia para períodos de controle e de convivência das plantas daninhas em culturas anuais e bianuais. In: Congresso Brasileiro de Herbicidas e Plantas daninhas, 15, Belo Horizonte, 1984. Resumos. p.37.

QASEM, J.R. Pigweed (Amaranthus spp.) interference in transplanted tomato (Lycopersicon esculentum). Journal Hortiscience, v.67, n.3, p.421-427, 1992.

ROBERTS, H.A.; HEWSON, R.T.; RICKETTS, M.A. Weed competition in drilled summer lettuce. Horticulture Research, v.17, n.1, p.39-45, 1977.

SALVADOR. F.L. Manejo e interferência das plantas daninhas em soja: Uma revisão. Revista da FZVA, v.13, n.2, p.58-75. 2006.

SANCHEZ, W. Herbicidas dimethenamid e metolachor na cultura da alface "Elisa". Tese (Mestrado) Universidade Federal do Mato Grosso do Sul - UFMS, Dourados. 1999. $42 f$.

SANTOS, B.M.; DUSKY, J.A.; STALL, W.M.; GIREATH, J.P. Influence of common lambsquarters (Chenopodium album) densities and phosphorus fertilization on lettuce. Crop Protection, v.23, n.2, p.173-176, 2004.

SHREFLER, J.W.; SHILLING, D.G.; DUSKY, J.A.; BRECKE, B.J. Influence of phosphorus fertility on intra- and interspecific interference between lettuce (Lactuca sativa) and spiny amaranth (Amaranthus spinosus). Weed Science, v.42, p.574-578, 1994b.

SILVA, A.C.; SANTOS, H.S.; SCAPIM, C.A.; CONSTANTIN, J. Efeitos de diferentes períodos de controle e convivência de plantas daninhas na cultura da alface (Lactuca sativa). Acta Scientiarum. Agronomy, v.21, n.3, p.473-478, 1999.

SOARES, D.J.; PITELLI, R.A.; BRAZ, L.T.; GRAVENA, R.; TOLEDO, R.E.B. Períodos de interferência das plantas daninhas na cultura da cebola (Allium cepa L.) transplantada. Planta Daninha, v.21, n.3, p. 387-396, 2003.

SWANTON, C.J.; WEISE, S.F. Integrated weed management: the rationale and approach. Weed Technology, v.5, n.3, p.657- 663, 1991.

ZÁRATE, N.A.H.; SANGALLI, C.M.S.; VIERA, M.C.; GRACIANO, J.D.; MUNARIN, E.E.O.; PAULA, M.F.S. Cobertura do solo com cama-de-frango, com e sem amontoa, na produção de beterraba. Ciência e Agrotecnologia, v.34, Edição Especial, p. 1598-1603, 2010. 